\title{
Social-Media Driven: The Phenomenon and Existence of Mainstream Online Media in Disruption Era
}

\author{
$1^{\mathrm{st} *}$ Achmad Rouzni Noor II \\ Communication Department \\ University of Indonesia \\ Depok, Indonesia \\ rourry@gmail.com
}

\author{
$2^{\text {nd }}$ Niken Febrina Ernungtyas \\ Communication Department \\ University of Indonesia \\ Depok, Indonesia \\ nikenfebrina@gmail.com
}

\begin{abstract}
The presence of social media has changed the habits of readers when searching for actual information. This phenomenon driven by social media can threaten the existence of mainstream media based online. In Indonesia, many new media are emerging thanks to the ease of social media and citizen journalism participation. As a result, this condition has the potential to disrupt the online media business market. From the phenomenon of social media-driven, the authors conducted a study with a qualitative approach by means of observation and interviews, and examined the study of literature to examine mainstream media strategies in anticipating threats that exist in the era of social media and react to them as opportunities for future gains.
\end{abstract}

Keywords- social media, online media, disruption, mainstream media, social-media driven

\section{INTRODUCTION}

Humans as social creatures continue to create technological innovations to meet their needs in communicating and getting actual information. Since entering the internet era in 1995, the need for that information can be obtained, thanks to the presence of mainstream online media based [1] Online media or news portals were initially only accessible using technological devices such as desktop computers (personal computers) and portable computers (laptops or notebooks). Then, online media has grown more rapidly since the presence of gadget devices such as smartphones and tablets that are more personal because they are easy to carry on.

The development of access device technology has made online media companies competing to develop their multiplatform journalistic content business. First, through the website so that it can be accessed via an internet browser, both on desktop and on mobile. Furthermore, to make it easier, an application was made to facilitate user access through the gadget.

Mostly, online media in Indonesia are conventional printbased media companies, for example from newspaper businesses such as Kompas, Sindo, Tribunnews, and Media Indonesia. From the business magazines such as Tempo and Gatra. Then, from the tabloid business such as Nova and Pulsa. Conventional electronic media based also being mediamorphosis and plunged into online media businesses, for example from television businesses such as Liputan6, MetroTV, MNC, and ANTV [2]. The entire media company was tempted by the digital media business market, which had already been dominated by Detik.com, which since 1998 had already plunged directly into the online media business. All of them are competing to establish new media based online with the motives of media economy. The first trial attempt was carried out by Kompas Daily with Kompas.com, MNC with Okezone.com, and ANTV through Vivanews.com (now Viva.co.id).

Based on the author's experience who had worked for 15 years at Detik.com, the media house which was formerly named PT Agranet Multicitra Siberkom, was gaining huge revenues from the digital advertising business. The key is in terms of users and traffic. The more users, the higher the traffic, the faster Detik.com sells online advertising. In fact, the digital advertising market share in Indonesia, was controlled by $80 \%$ by Detik.com since its inception until 2010 .

Still from the author's perspective, the success of Detik.com to become the ruler of the online media market since its inception is speed, according to the philosophy of its name that uses the fastest time unit. All news must be quickly presented in seconds. This breaking news-style formula is then observed, emulated, and modified by print and electronic based mainstream media which are now direct competitors in the realm of online media.

The faster the online media preaches, the hope is of course, the faster the information from the field reaches the public. The faster it is accessed by the grabbing hands of smartphone gadgets - and computers, that means the higher the traffic. The higher the traffic, the better the online media's behaviour in selling advertisements. From the company side, such a business scheme is very positive. However, in terms of journalistic, it is sometimes considered to be lacking cover both sides, inaccurate, and often found incorrect facts, because the presentation is very hasty. The precautionary factor usually found in conventional media has to be pushed aside in order to be the fastest in presenting news.

By seeing all the conveniences offered by the internet in registering domain names, making online media business so attractive despite the bubble in the dot com business in early 2000. The internet can be described as 'the new promised land', a new business field that promises a million hopes. That is why until 2016, the Press Council noted that there were already 43 thousand online media operating in Indonesia. But unfortunately, 40 of them are still not verified according to 
journalistic standardization and have the potential to become a hoax producing media. that is what ultimately led the Press Council to issue cyber media news guidelines.

Before the "honeymoon" in the online media business, the internet spreads proof new hope with the born of social media. This phenomenon begins with the birth of Facebook in 2005. Everyone can share any content, including the ease of disseminating information, making Facebook instantly a new ruler in business on social media. Total Facebook users in the world currently has reached 1.3 billion and followed by Instagram with 1 billion users. All the conveniences spoiled by social media, including in facilitating the ease of uploading content, make many parties competing to become content creators. Whoever succeeds in producing the most interesting content, has many automatic followers.

The ease of sharing content also makes content creators become celebrities on social media. Content producers who succeeded in creating viral content, must have a high engagement, and make them ogled by marketing companies as a new field of selling advertising, endorsement, because it succeeded in drawing the attention of citizens - as known as the netizens.

The ease of sharing information on social media also makes many citizen journalists are existing on social media. No matter whether the content posted is a work of its own production, or just sharing content, quote here and there for the sake of participatory journalism. Sometimes, rumors are easily spread without confirmation, as long as the content makes a scene and keeps the engagement rate high.

Such fragile information turns out to be of interest to the public on social media. The Lambe Turah gossip account, for example, could draw the attention of 7.2 million netizens to continue following them. The number of followers of this account is far higher than official social media accounts belonging to mainstream media like Detik.com, even those with only 2.2 million followers.

On social media, new media accounts that are not from press companies actually get a greater number of followers. In addition to Lambe Turah, the WowFakta account has 6.4 million followers, Indozone 3.5 million followers, while online mainstream media accounts such as Kompas.com are only followed by 770 thousand and Tribunnews.com only 775 thousand followers.

Based on the author's experience when he was still appointed as the Managing Editor of Detik.com, this era of social media has made the industry map in online media change. Not only competing with speed to surpass fellow online media, but also must compete to capture the attention of netizens on social media, so that the influence of online media such as Detik.com cs is not eroded by Lambe Turah cs. From this social media-driven phenomenon, the author intends to conduct research with a qualitative approach to conduct observations and study of literature to examine the online-based mainstream media strategy in anticipating threats that exist in the era of social media and to treat them as opportunities for future profits.

\section{RESEARCH METHOD}

In this research about social media-driven phenomena, the writer uses a qualitative approach to observe and study literature in order to examine the mainstream online media strategy in anticipating threats that exist in the era of social media and treat them as opportunities for future profits.

The qualitative approach in question is a descriptive analysis whose purpose is to explore phenomena that cannot be measured quantitatively. While the techniques for collecting data through observation, starting from what is seen directly by the author, felt the changes, and of course experienced directly in daily life while working in the online media industry.

When the authors carry out research with a qualitative approach, the data analyzed comes from the results of field observation [3]. Thus, in analyzing the data the author uses the matrix method, including data reduction, data display, conclusion drawing, and validation Miles and Huberman (1994). The observation made by the author is to use the method of observing the habits of online media and social media in preaching, in conveying narratives, which ones are of more interest to the reader. The author also interviewed managers of online media and social media about this phenomenon. The purpose of this interview is to get responses and views on the changing social media industry that is increasingly social media driven.

The results of this interview will also be explored about the meaning and development of social media, how its workers find data, process it into information, and publish it into interesting content. This observation technique is also carried out on the reflective development of the writer during his work as a journalist as well as managing editor, which is then analyzed through a narrative strategy based on theory.

\section{RESULT AND DISCUSSION}

Technological developments such as the internet and computing devices have spawned a new media era and created disruption in the media industry, while at the same time encouraging the lifestyle of media consumers. Thus, the character of the media shifted, starting from the beginning of the process of searching and processing news to the distribution of content.

The ease of accessing the internet is also driven by technological developments through cellular connections that have entered the $4 \mathrm{G}$ era and wireless broadband connections via WIFI which are supported by broadband infrastructure. In the end, the internet makes online media grow rapidly. The presence of a smartphone with its application store helped make social media grow rapidly.

The presence of increasingly sophisticated mobile devices such as smart phones or smartphones has eroded the desktop computer industry. the impact of online media is now unmatched by social media. Ease of access through applications on mobile phones makes people choose media that is easier, closer, and more like the narrative, despite the fact that people do not consume enough just one media to get a lot of information. 


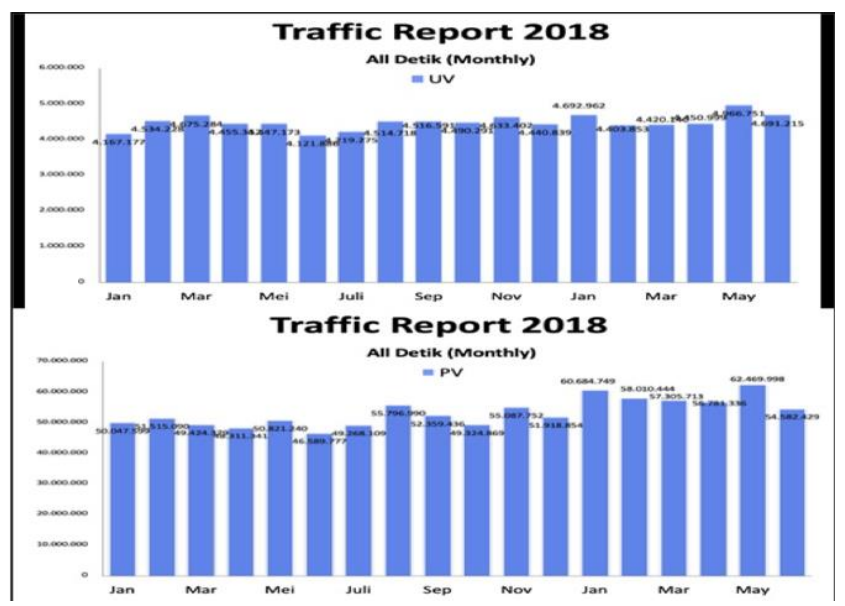

Fig. 1. Traffic Report Detik.com during January 2017 - June 2018. Source: Private document. (2019)

The proliferation of new media on social media is also recognized by the author as a threat to mainstream online based media. From the writer's notes when he was still serving as Managing Editor at Detik.com in 2016-2018, the largest online media reader traffic in Indonesia is stagnant with five million unique visitors (UV) per day with pageviews (PV) ranging from 60 million to 70 million news pages that haven been read per day. If the total readers of detikcom are assumed to represent the majority of internet users in Indonesia who read online-based mainstream media, that means, the percentage is only 3.3 percent compared to the number of internet users who had reached 150 million in Indonesia at that time (Google \& Temasek, 2018). The question is, where do the majority of other internet users look for news information? As stated from Nukman Luthfie, the expert and practitioner of digital media [4] social media has become the new mainstream media in the digital era, because the content and information needed is so easily found on Facebook, Twitter and Instagram.

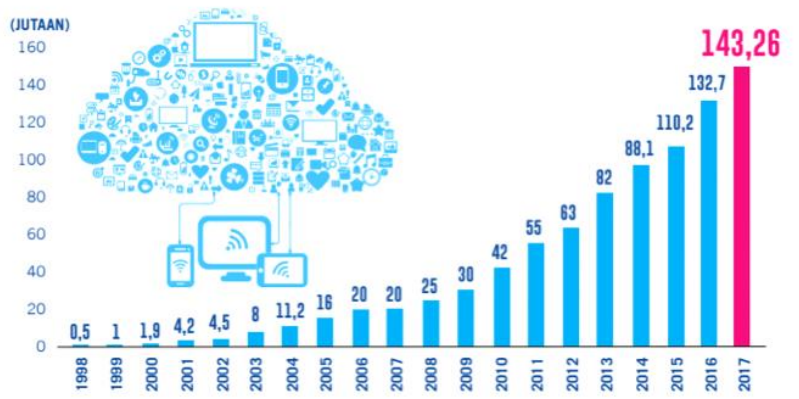

Fig. 2. Growth of internet users in Indonesia (1998-2017) Source: APJII (2018)

According to a survey conducted by APJII [5], social media is accessed by internet users in Indonesia with a percentage of 87.13 percent. Social media is the second largest application accessed by internet users in Indonesia via smartphones. While research on We Are Social and Hootsuite (2019), states that there are 150 million social media users in Indonesia. Apparently, Facebook is known to be the most popular in Indonesia and Instagram ranks second with $80 \%$ penetration.
While based on Google (2018), 94\% of internet users in Indonesia have actively used smartphones. With the 2019 projection, where internet users in Indonesia are estimated to reach 175 million people, it can be predicted, people who access via smartphones will penetrate 164.5 million. That means, the chance of the number of users looking for information from social media will be even the greatest one.

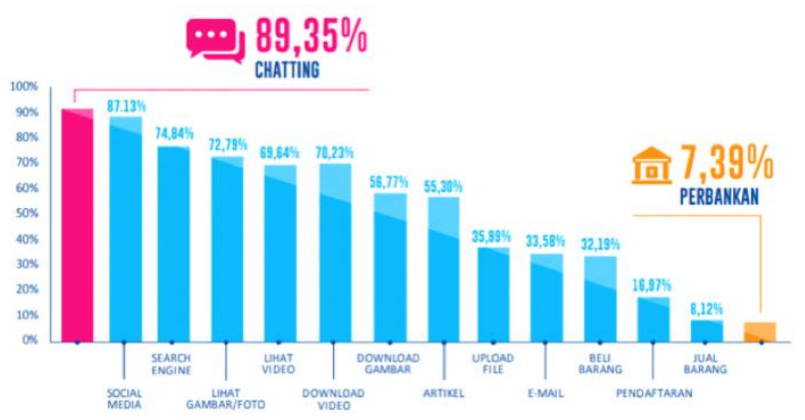

Fig. 3. The platform which were accessed by using internet in 2017. Source: APJII (2018)

The tendency of social media to become a new source of information like mainstream media is the presence of an account called Lambe Turah on social media Instagram. This account often leaks information about celebrity gossip in Indonesia. The information is much faster than online media such as Detik.com. No wonder, if the number of followers of Lambe Turah on Instagram (6.6 million as of May 2019) far exceeds the official accounts of mainstream media such as detikcom (1.4 million as of May 2019). Detik.com is even beaten down by new media such as WowFakta which has 6.4 million followers and Indozone which covers 3.5 million followers.

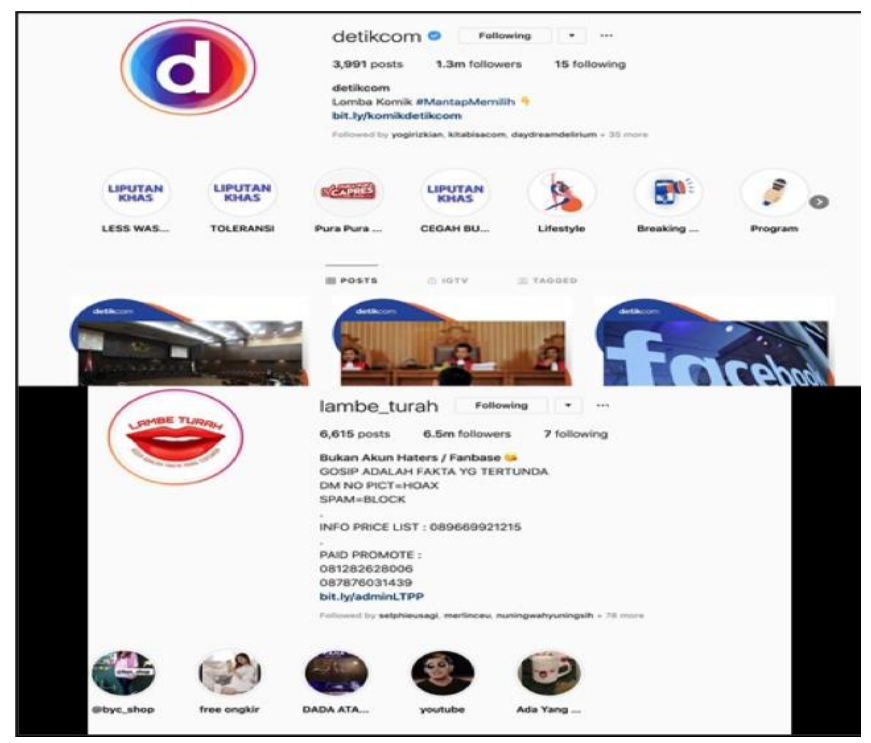

Fig. 4. Instagram account Detik.com and Lambe Turah (2018). Source: Screenshot@detikcom and @lambe_turah

Lambe Turah, WowFakta, and Indozone, are examples of new media in the era of social media. Since gaining popularity in social media, the trio have even slowly joined the mainstream online media business and began to have an editorial crew and a production team like mainstream media institutions like Detik.com. The popularity of Lambe Turah 
and friends finally inspired many similar accounts to establish new media on social media. In addition, as a reference for new sources of information, they aim to get economic benefits.

In the world of digital marketing, Lambe Turah, WowFakta, and Indozone, are categorized as influencers on social media (Lin, Li, \& Wu. He mentioned, there are three special characteristics about influencers in question, namely (1) as forming public opinion on social media, (2) being able to communicate with a broad audience that is anonymous, (3) and known directly by the public without industry intermediaries. This condition ultimately disrupts the mainstream media that rely on advertising as a source of income, as revealed by Schumpeter in Todd (2011).

The presence of accounts such as Lambe Turah cs, borrowing the ideas of Andreas Kaplan and Michael Haenlein (2010) [6], can occur thanks to internet-based applications that are the basis in the development of Web 2.0 technology that allows the content created by its users (user-generated content). While Barassi and Treré [7] explained that with websites and applications based on user-generated content that prioritizes citizen journalism, internet users are no longer passive readers of the media, they can also be consumers and producers of content.

This situation helped to inspire the author when he founded Urban Asia Media. Starting from making new media on social media with the name @ urbanasiacom in 2018, and in 2019 this media is expanding its business wing in online media with the domain names www.urbanasia.com. It also reflects from survey data released by APJII where half of internet users in Indonesia (55.3\%) still use their access to read news articles. While data from We Are Social (2017) active social media users on mobile devices rose from 66 million to 92 million users.

The shift from conventional media to digital is indeed recognized as part of the new media era, and online media is a product of new media in the digital era itself. Online media has the advantage of quickly conveying information, up to date news, information is never left behind, free, can be accessed from anywhere. Moreover, from the author's experience and the results of interviews with a number of online and social media managers, people in Indonesia are news literate, and social media is an alternative in finding information. The following statement from one of the media managers at Detik.com:

Semua orang di zaman digital ini bisa bikin website, bisa bikin media, siapapun itu. Karena dimudahkan oleh teknologi yang ada saat ini. Kita bisa bikin akun sendiri, bikin website sendiri, akhirnya kita bebas. Bahkan, kalau media mainstream itu cuma mencantumkan pedoman media siber di bawah dan didaftarkan di Dewan Pers, itu sudah bisa diakui jadi media online. (Managing Editor Detik.com, 2019).

While online media manager Tribunnews.com claimed not to want to miss the trends that occur in social media. Whatever the case is being crowded in the community and discussed on social media, Tribunnews.com must participate in reporting quickly so as not to lose moment.

Kami selalu mengikuti apa yang menjadi tren $d i$ masyarakat. Semua yang terjadi di masyarakat biasanya ramai dibahas di media sosial. Masak di media sosial sudah ramai, kita kok nggak ikut membahas? Itu cara kami untuk menarik perhatian massa yang ada di media sosial. (Pemimpin Redaksi Tribunnews.com, 2019).

On the other hand, the manager of social media $@$ urbanasiacom and online media Urbanasia.com see that anyone on social media can become an interesting content producer.

Seтиа orang di media sosial bisa menjadi produsen konten. Siapa yang bikin konten paling menarik biasanya langsung viral karena disebarkan mulai dari lingkup pertemanan terdekatnya hingga akhirnya ramai dibahas masyarakat luas. Jika konten yang diposting sangat kuat, biasanya menjadi trending topic. Imbasnya, akun produsen konten tersebut bertambah pengikutnya (Editor in Chief Urbanasia.com, 2019).

In fact, in seeing the phenomenon of the Lambe Turah account cs that concerns the author in the concept of disruption of the mainstream media, it has been explained a long time ago by Katz, Blumler, and Gurevitch (1973) [8]. They explain that the presence of 'disruption' or 'disruption' is also due to human nature that is not easily satisfied. According to them, we choose certain media that can fulfill our needs. According to the theory, people are self-aware, and they can explain why they use media. In addition, this theory emphasizes the relationship of active audiences with the use of media because it has a definite purpose.

The Uses and Gratification assumptions from Katz, Blumer, and Gurevitch (West and Turner, 2008), explain 2 things namely the use of media because it has a purpose and satisfaction of needs. It distinguishes between online-based mainstream media and social media carrying news information. The mainstream media cannot be separated from the rules of journalism. This online media is an agency or company that houses the press workers.

In accordance with Law No.40 of 1999 concerning the Press, journalists themselves must produce content routinely and comply with the journalistic code of ethics [9] A journalist or press worker must carry out such activities routinely, every day. Online-based mainstream media in Indonesia is bound by the Code of Ethics of the Press Council, an association that houses the news processing industry. Online-based mainstream media must obey the nine rules contained in the Guidelines for Media News Coverage. So, we can see that cyber media or online-based mainstream media has a special model in the operational process. This is not owned by social media whose content is produced by citizen journalists [10]

Even so, when we are in a website-based media environment, it becomes different. Because the information presented by social media can be disseminated massively and will be read in many different people's perspectives and perspectives. That is what then makes the emergence of new media will be far more interactive and massive compared to traditional mass communication [11]

Moreover, the life cycle of readers who live in a dynamic social environment will continue to spin [12]. Thus, a new medium is needed in the media industry so that public demand for diverse and fast information can be obtained easily. 


\section{CONCLUSION}

From this research, we conclude that the development of internet has changed the landscape of media as the medium for accessing information and news. Not only mainstream media from conventional media, such as printed media, radio or even television, but also the appearance of social media in this era that raise new media and also the participation of citizen journalism.

Meanwhile, the existing of social media which are very flexible and more interesting than mainstream media can threaten the growth of mainstream media. For example, Detik.com cs which proved to be outnumbered by users and engagement when compared to Lambe Turah or other new media who were faster and more flexible because they did not use journalistic rules according to regulations, especially applicable cyber media guidelines.

As a result, the speed of information flow on social media makes online-based mainstream media shattered, their prestige eroded and the influence of this mainstream media as a reference in getting information is diminishing. The presence of social media has become a disruption in reader behavior when searching for actual information. Even though the mainstream online media are bound by the guidelines of cyber media reporting, Detik.com cs can still outsmart by making narratives that are more easily digested by the public, lighter in presenting content, more attractive in audio and visual packaging, as is usually done by new media on social media.

The writers hope, from this research, online-based mainstream media still remains a public reference because it can be trusted, but on the other hand the way it is presented becomes more interesting. Thus, the pattern of public consumption of the mainstream media is maintained, and in terms of the media economy, its market share is not disturbed by new media on social media, it can even be much more increased than before.

\section{ACKNOWLEDGMENT}

In writing this research paper, the writer get a best support from kindness people at the University of Indonesia. Another assistance was also obtained by the writer from Healza Kurnia who became a partner in developing the writer's business in Urbanasia Media. Thank you to a special human named Silvia Noor, Athalla, Keefe, Keenan, and Nadhifa who provided support in completing this paper. Not to forget, the authors also offer gratitude to Allah SWT who is so good for the past 40 years and continues to provide opportunities for writers to continue working.

\section{REFERENCES}

[1] C. Juditha, "Akurasi Berita dalam Jurnalisme Online (Kasus Dugaan Korupsi Mahkamah Konstitusi di Portal Berita Detiknews)," J. Pekommas, vol. 16, no. 3, pp. 145-154, 2013.

[2] L. Muliawanti, "JURNALISME ERA DIGITAL: DIGITALISASI JURNALISME DAN PROFESIONALITAS JURNALISME ONLINE," LENTERA J. Ilmu Dakwah dan Komun., 2018, doi: 10.21093/lentera.v2i1.1168.

[3] M. Q. Patton, Qualitative Research \& Evaluation Methods, 3rd ed. California: Sage Publication, 2002.

[4] Indopos, "Media Mainstream Sekarang adalah Medsos," 2017.

[5] APJII, "APJII: Penetrasi Pengguna Internet Indonesia Capai 143 Juta Orang.," 2017. [Online]. Available: https://dailysocial.id/post/apjiisurvei-internet-indonesia-2017. [Accessed: 26-Mar-2019].

[6] A. M. Kaplan and M. Haenlein, "Users of the world, unite! The challenges and opportunities of Social Media," Bus. Horiz., 2010, doi: 10.1016/j.bushor.2009.09.003.

[7] V. Barassi and E. Treré, "Does Web 3.0 come after Web 2.0? Deconstructing theoretical assumptions through practice," New Media Soc., vol. 14 , no. 8 , pp. 1269-1285, 2012, doi: $10.1177 / 1461444812445878$.

[8] E. Katz, J. G. Blumler, and M. Gurevitch, "Uses and Gratifications Research," Public Opin. Q., 1973, doi: 10.1086/268109.

[9] P. W. Indonesia, "UU Pers," 2012. [Online]. Available: https://pwi.or.id/index.php/uu-kej. [Accessed: 27-Mar-2019].

[10] B. Mutsvairo, Participatory Politics and Citizen Journalism in a Networked Africa. New York: Palgrave Macmillan, 2016.

[11] D. Mc Quail, McQuail's Mass Communication Theory, 6th editio. London: SAGE Publications Ltd, 2010.

[12] M. Dekavalla, "The Scottish newspaper industry in the digital era," Media, Cult. Soc., vol. 37, no. 1, pp. 107-114, 2015, doi: $10.1177 / 0163443714553565$. 